\title{
Calculation of the digestibility for ruminants of roughages from their contents of cell-wall constituents. II Time-saving method of analysis
}

\author{
Blanche D. E. Gaillard and H. J. Nijkamp \\ Department of Animal Physiology, Agricultural University, Wageningen, The Nether- \\ lands
}

Received 21 July, 1967

\section{Summary}

A tince-saving modification is given of an analysis of some cell-wall constituents of roughages from which the digestibility of the organic matter for ruminants can be calculated.

\section{Introduction}

In a previous communication (Gaillard, 1966) a method was proposed for the determination of the cell-wall constituents of roughages. From these the digestibility for ruminants of the organic matter could be calculated with the following regression equation:

$\mathrm{DOM}=-5.51(\mathrm{~L}-5.58)+0.37(\mathrm{C}-19.19)-0.51(\mathrm{H}-18.10)+$ $4.11(\mathrm{U}-3.80)+65.1$

In which $\mathrm{DUM}=$ digestibility of the organic matter, $\mathrm{L}=\%$ lignin in dry matter, $\mathrm{C}=\%$ cellulose in dry matter, $\mathrm{H}=\%$ hemicellulose in dry matter and $\mathrm{U}=\%$ anhydro-uronic acid in dry matter.

It appeared that this regression equation which was obtained from the analyses of 29 roughages (legumes and grasses) with a great variety in digestibilities could be used also for other types of roughages resulting in the same standard deviation of 3.2. Although the method is quite simple in handling it was felt that for routine purposes it was time-consuming. Statistical analyses show that the influence of the lignin and of the anhydro-uronic acid contents on the digestibility of the organic matter is the most important while the influence of hemicellulose and cellulose is much less. Hence, in trying to limit the amount of analytical work to be done, the possibility of eliminating separate determinations of the cellulose and hemicellulose contents and at the same time maintaining the lignin and anhydro-uronic acid determinations should be investigated. For this there are three possibilities:

1) Determination of total cell-wall contents instead of the contents of lignin, cellulose and hemicellulose separately. The residue of the treatment with neutral detergent, NDR (van Soest, 1963), consists mainly of these three components. In addition to the method used by Maasland (6). 
Table 1 Correlation coefficients and residual standard deviations

$$
\text { Correl. coeff. Stand. dev. }
$$

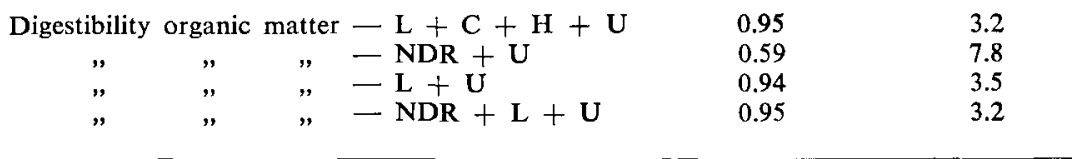

The correlation between organic matter digestibility and NDR + anhydro-uronic acid appeared however to be poor, correlation coefficient 0.59 with a standard deviation of 7.8 (Table 1).

2) Determination of lignin and anhydro-uronic acid. This gave a correlation coefficient of 0.94 with a standard deviation of 3.5 (Table 1).

3) Determination of the contents of NDR, lignin and anhydro-uronic acid. With this set the same correlation coefficient of 0.95 and standard deviation of 3.2 were found as with the originally proposed analysis. Although, for the determination of lignin, hydrolyses with $5 \%$ and $72 \%$ sulphuric acid are still required, the length of time required for determining the sugars in the filtrates from which the contents of hemicelluloses and cellulose are to be calculated is saved. As some roughages contain relatively smalle amounts of lignin it is recommended to perform the analysis on $\pm 4 \mathrm{~g}$ of airdry material instead of on $2 \mathrm{~g}$.

\section{Method}

Reagents:

1) neutral detergent solution: $30.0 \mathrm{~g}$ sodium lauryl sulphate; $18.61 \mathrm{~g}$ disodium dihydrogen ethylenediaminetetraacetate, dihydrate; $6.81 \mathrm{~g}$ sodium borate decahydrate; $4.56 \mathrm{~g}$ disodium hydrogen phosphate.

Dissolve each of these ingredients in some distilled water and mix the solutions. Add $10 \mathrm{ml}$ ethylene glycol and make up to $1000 \mathrm{ml}$. Check the $\mathrm{pH}$ of the solution to be within the range of $6.9-7.1$. Adjust with concentrated sodium hydroxide if necessary.

2) $5 \%(\mathrm{~N})$ sulphuric acid.

3) $72 \%(24 \mathrm{~N})$ sulphuric acid.

4) $0.1 \mathrm{~N}$ hydrochloric acid.

5) $0.1 \mathrm{~N}$ sodium hydroxide.

\section{Determination}

$4 \mathrm{~g}$ of airdry material is boiled gently for one hour under reflux with $300 \mathrm{ml}$ of the neutral detergent solution. The residue is collected on a large sintered glass filter (Jena 17G2). It is washed once with $0.1 \mathrm{~N}$ hydrochloric acid whereafter the residue in the filter is kept covered with $0.1 \mathrm{~N}$ hydrochloric acid for 30 minutes. The residue is washed with distilled water until free of acid and dried with acetone. Residual acetone is evaporated away overnight. The following determinations are carried out on this residue (NDR). 
Determination of the dry matter content

This is carried out on $\pm 0.500 \mathrm{~g}$ of the residue (NDR) at $100^{\circ}-105^{\circ} \mathrm{C}$. The dry NDR is expressed as a percent of the original roughage dry matter which has been measured separately.

\section{Determination of the content of anhydro-uronic acid}

$\pm 0.300 \mathrm{~g}$ of the residue is stirred for some minutes with $0.1 \mathrm{~N}$ sodium hydroxide with the exclusion of air. The excess of sodium hydroxide is titrated with $0.1 \mathrm{~N}$ hydrochloric acid using phenolphthalein as indicator. $1 \mathrm{ml}$ of $0.1 \mathrm{~N}$ sodium hydroxide used $=17.6 \mathrm{mg}$ anhydro-uronic acid. The content of anhydro-uronic acid is also calculated as a percent of the roughage dry matter.

\section{Determination of the lignin content}

The remainder of the residue is hydrolysed by boiling under reflux for three hours with $150 \mathrm{ml}$ of $5 \%$ sulphuric acid. The acid is filtered off and the residue is washed several times with water and finally dried with acetone. The residue is transferred to a tube (40-50 ml capacity) with a ground-glass stopper and $15 \mathrm{ml}$ of $72 \%$ sulphuric acid and 15-20 glass beads $(5 \mathrm{~mm}$ diam.) are added. The tube is shaken vigorously by hand for some minutes to break up all lumps whereafter it is shaken mechanically for four hours at a temperature of $20^{\circ} \pm 2{ }^{\circ} \mathrm{C}$. The contents of the tube are then transferred into an Erlenmeyer flask with $350 \mathrm{ml}$ of water and boiled under reflux for two hours. When still hot the mixture is filtered over a weighed ashfree filter and washed with water. The residual lignin on the filter is dried at $100^{\circ}-105^{\circ} \mathrm{C}$, weighed and incinerated. The weight of the lignin, found by difference, is also calculated as a percent of the roughage dry matter.

In case the NDR content is low (young material) and there would not be enough residue available for all three determinations it is possible to carry out the anhydrouronic acid and lignin determinations on one sample by first titrating the anhydrouronic acid on the amount of NDR which is available for both determinations and thereafter adding enough $72 \%$ sulphuric acid and water to make the final concentration $5 \%$ in sulphuric acid. Then the procedure of hydrolysis can be carried out as usual.

The digestibility of the organic matter can now be calculated with the following formula:

$\mathrm{DOM}=-4.64(\mathrm{~L}-5.19)-0.14(\mathrm{NDR}-48.05)+2.95(\mathrm{U}-3.47)+66.7$

in which $\mathrm{DOM}=$ the digestibility of the organic matter and $\mathrm{L}, \mathrm{NDR}$ and $\mathrm{U}$ are lignin, neutral detergent residue and anhydro-uronic acid as a percent of the roughage dry matter.

\section{Discussion}

By applying the above-mentioned equation it is possible to predict the organic matter digestibility of a great variety of roughages fairly accurate. In this way however, entire information about the composition of the cell-wall is not obtained. For routine purposes such a detailed information is not necessary. In cases where it is desirable to know the actual percentages of hemicelluloses and cellulose the analysis can easily be extended with the sugar determinations on the filtrates of the hydrolyses with $5 \%$ and $72 \%$ sulphuric acid which are obtained during the lignin determination. 
Often it is of interest to calculate not only the digestibility of the organic matter of a roughage but also the starch equivalent value. This value is at present calculated with the aid of the percentages of the digestible organic matter and the crude fibre. It is however possible to calculate the starch equivalent value from the organic matter digestibility without knowing the crude fibre content (van Es and Gaillard) using the following equation:

$\mathrm{SE}=\mathrm{DOM}-\mathrm{a}(100-\mathrm{DOM})-0.06 \mathrm{DCP}$

in which $\mathrm{SE}=$ starch equivalent value, $\mathrm{DOM}=$ digestible organic matter in $100 \mathrm{~g}$ dry matter, $\mathrm{DCP}=$ digestible crude protein in $100 \mathrm{~g}$ dry matter and $\mathrm{a}=0.49$ for hay and similar materials, 0.24 for grass and similar materials and 0.37 for silage.

\section{Keferences}

Es, A. J. H. van and Gaillard, B. D. E. De zetmeelwaarde van voedervet en van ruwvoer voor rundvee. Veeteelt en Zuivelber. (In press)

Gaillard, B. D. E., 1966. Calculation of the digestibility for ruminants of roughages from the contents of cell-wall constituents. Neth. J. Agric. Sci., 14: 215-223.

Soest, P. J. van, 1963. Use of detergents in the analysis of fibrous feeds. J.A.O.A.C., 46: 825-829. 